\title{
EPITHERMAL MANGANESE MINERALIZATION, KIMOLOS ISLAND, SOUTH AEGEAN VOLCANIC ARC, GREECE
}

\author{
Lykakis, N. ${ }^{1}$ and Kilias, S. P. ${ }^{2}$ \\ ${ }^{1}$ Grant Institute of Earth Science, School of Geosciences, University of Edinburgh, EH9 3JW, \\ Scotland,UK,nikoslykakis@gmail.com \\ ${ }^{2}$ Department of Geology and Geoenvironment, University of Athens, 15784 Zographou, Greece, \\ kilias@geol.uoa.gr
}

\begin{abstract}
Manganese mineralization is hosted by a marine monomictic, lithic volcaniclastic breccia, possibly an andesitic in situ hyaloclastite, and shallow-marine or subaerial epiclastic conglomerates, in the Korakies area, NE Kimolos, active south Aegean volcanic arc. Old mine workings (in the form of rubble, adit and shaft), and abandoned rail and ship loading facilities, exist in the area. Mineralization occurs as a quartz/chalcedony vein system filling extensional NNE-SSW-trending faults and fractures, of Pliocene age. Maximum vein width reaches $5 \mathrm{~m}$; length may extend to $250 \mathrm{~m}$. The ore shares strong textural analogies with volcanic-hosted epithermal-style deposits, i.e. crustiform banding, vugs, hydrothermal breccias, cockade and comb textures. Vein wall rocks are hydrothermally altered to quartz-adularia \pm illite, chlorite and barite. Pyrolusite, hollandite, cryptomelane, and coronadite are the main ore minerals, with quartz, chalcedony, jasper and barite gangue. Ore samples contain up to $25.8 \% \mathrm{MnO}_{2}, 14.7 \% \mathrm{FeO}_{\mathrm{TOT}}, 2860 \mathrm{ppm} \mathrm{Zn}, 1132 \mathrm{ppm} \mathrm{Pb}$ and $136 \mathrm{ppm} \mathrm{Cu}$; $\mathrm{Mn}$ and $\mathrm{Zn}$ show mutual positive correlation $\left(r^{2}=0.61\right)$. Trace element enrichment (i.e. $\mathrm{Zn}, \mathrm{Pb}$, and $\mathrm{Cu}$ ) may suggest a proximal base metal sulfide mineralization. Concentrations of $4.3 \% \mathrm{Na}, 0.09 \% \mathrm{Mg}$ and barite presence may suggest genetic involvement of sea water. The mineralization studied is similar to volcanic-hosted low-sulfidation epithermal ore deposits deposited from neutral $\mathrm{pH}$ fluids. This is a rare example of a vein-type epithermal-style hydrothermal manganese deposit formed in a marine environment.
\end{abstract}

Key words: epithermal manganese, Kimolos, South Aegean Volcanic Arc, hollandite, pyrolusite, cryptomelane, epithermal textures.

\section{Introduction}

Kimolos volcanic island $\left(36 \mathrm{~km}^{2}\right)$ shares a common geological evolution with Milos, Polyegos and Antimilos the Milos Group of the Pliocene-modern South Aegean volcanic arc (SAVA) (Pe-Piper and Piper, 2002). To date, metallic mineralization has only been reported from Milos, a dormant volcano that documents the transition between the submarine and terrestrial volcanic environments (Fytikas et al., 1986, Stewart and McPhie, 2006). Milos is host to a large inventory of volcanic-hosted metallic deposits (e.g. Hauck, 1984; Plimer, 2000; Liakopoulos et al., 2001; Kilias et al., 2001; Naden et al., 2005; Alfieris and Voudouris, 2007; Glasby et al., 2005) as well as industrial mineral deposits (Christidis, 2001, and references therein). Recent research on Milos has identified a new metallogenic environment - namely hybrid volcanic-hosted massive sulfide and continental magmato-hy- 


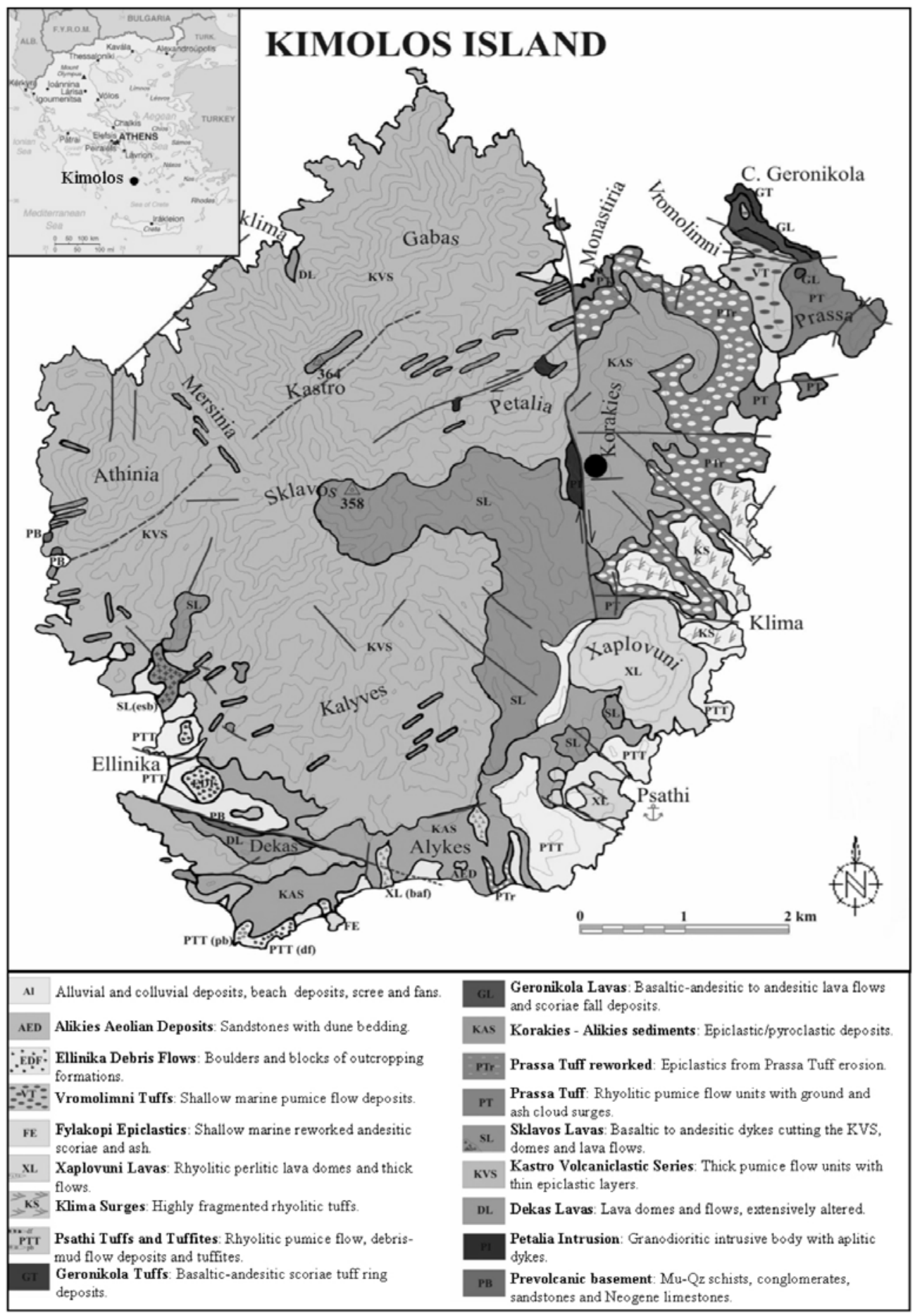

Fig. 1: Geological map of Kimolos Island showing the main structural features and the location of the Mn ore deposit in the Korakies area (black dot) (modified from Francalanci et al., 2007). 
drothermal mineralization (i.e. Profitis Ilias-Chondro Vouno $\mathrm{Au}-\mathrm{Ag}-\mathrm{Cu}$ deposit, Naden et al., 2005). In addition, epithermal and sea-floor exhalative textures have been documented in the Vani-Kondaros-Triades $\mathrm{Mn}-\mathrm{Ba}-\mathrm{Pb}-\mathrm{Zn}-\mathrm{Ag}$ hydrothermal field (Kilias et al., 2007, and unpublished data).

Published reports on the geology and hydrothermal mineralization on Kimolos are very scarce (Fytikas and Vougioukalakis, 1993, Pe-Piper and Piper, 2002; Francalanci et al., 2007); this is the first report on hydrothermal manganese mineralization that occurs in the Korakies area, NE Kimolos.

\section{Geological setting}

Volcanic centres of the Milos Group are positioned along NE-SW trending regional tectonic lineaments (Francalanci et al., 2007; Pe-Piper and Piper, 2002). Both Kimolos and Milos consist of marine and terrestrial lithologies with composition belonging to the calc-alkaline and high-K calc-alkaline series (Pe-Piper and Piper, 2002; Francalanci et al., 2007, and references therein). Volcanic activity occurred in two periods separated by a long serenity phase. Basaltic to rhyolitic lavas and voluminous pyroclastic rocks were erupted during the first period (3.5-2.0 Ma) in association with NE-SW-trending lineaments, whereas rhyolitic pyroclastic deposits and perlitic lava domes tied to NW-SE structural features, characterize the second period of activity (2.0-0.9 Ma) (Fig. 1). Structurally controlled NE-SW trending, active low-T $\left(\sim 55^{\circ} \mathrm{C}\right)$ geothermal activity, NW Kimolos is recharged mainly by seawater (Pe-Piper and Piper, 2002, Fytikas and Vougioukalakis, 1993).

The host rocks of the manganese mineralization form part of the Korakies-Alikes pyroclastic-epiclastic formation (Fig. 1). This formation consists of a mixture of shallow marine and subaerial pyroclastic and epiclastic lithologies, such as pyroclastic breccias and debris flows, sandstones and siltstones, and epiclastic conglomerates (Fytikas and Vougioukalakis, 1993). The mineralized structures crosscut an ENE-WSW trending monomict, andesitic volcaniclastic lithic breccia, and locally unconformably overlying epiclastic conglomerates. The volcanic rocks show a conspicuous flow texture with individual 2-3 m thick flow-beds trending ENE-WSW. Wallrocks constitute: (1) a clastsupported lithic breccia which contains angular to subangular andesite lava fragments with an average diameter of 20-30 cm, and a matrix of fine grained lava fragments of the same composition (Fig. 2C); this formation is topographically controlled and shows maximum thickness of $30 \mathrm{~m}$ best seen along paleo-valleys (Fytikas and Vougioukalakis, 1993). These rocks represent possibly submarine, lithicrich, volcaniclastic mass-flow deposits, or andesitic in situ hyaloclastites; (2) shallow-marine or subaerial epiclastic sediments which have clasts consisting of basaltic to andesitic Sklavos lavas (see Fig. 1) and Kastro volcaniclastics (see Fig. 1) cemented by hydrothermal silica. Host rocks come to a faulted N-S trending contact with the Kastro volcaniclastics to the east (Fig. 1).

\section{Manganese ore: occurrence and textures}

Abandoned mine workings (in the form of rubble, adit and shaft) and ship loading facilities, attest to past exploitation of the Mn deposit at Korakies. The deposit occurs in veins hosted exclusively by the Korakies pyroclastic/epiclastic formation. The exploited vein fills NNE-striking normal faults and related extensional fractures within a structural corridor of the regional Pliocene NE trend (PePiper and Piper, 2002). It has maximum width of 5-6 m, a length of at least $250 \mathrm{~m}$ and, dips $70^{\circ}$ to $90^{\circ}$ to the SW; the depth of the vein is unknown (Fig. 2A). The vein displays complex and multiepisodic filling with epithermal-style textures characteristic of open-space precipitation such as crustiform banding, vugs, hydrothermal breccias, and cockade and comb textures (Figs. 2D\&E\&F, Fig. 3A); breccia mainly occurs on the vein margins (Hedenquist et al., 2000) (Fig. 2E). These textures suggest that vein opening and filling was episodic, with several episodes of fault movement related 

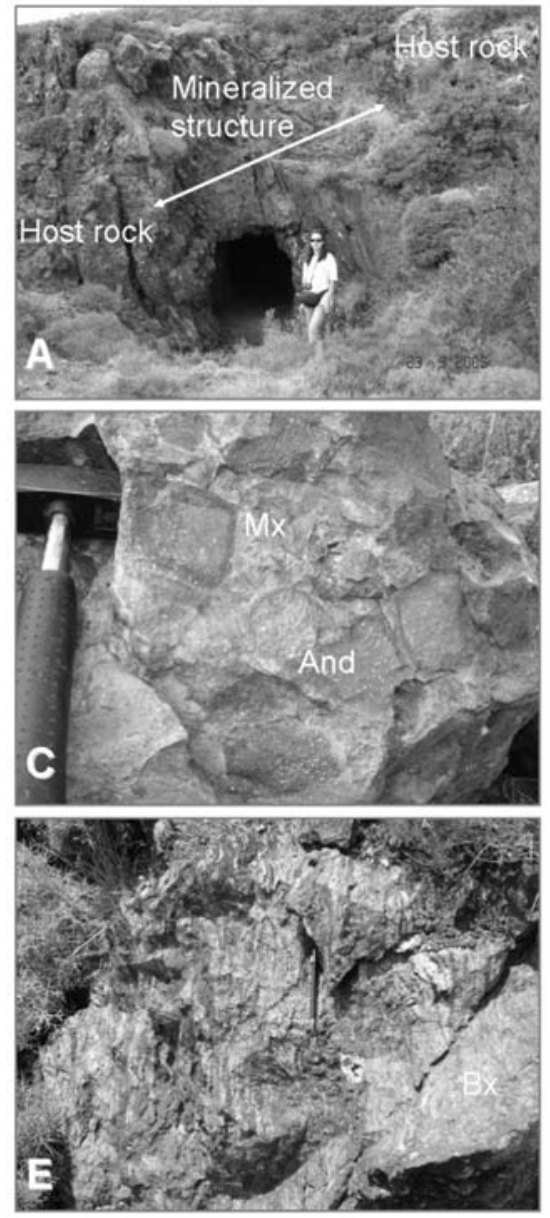
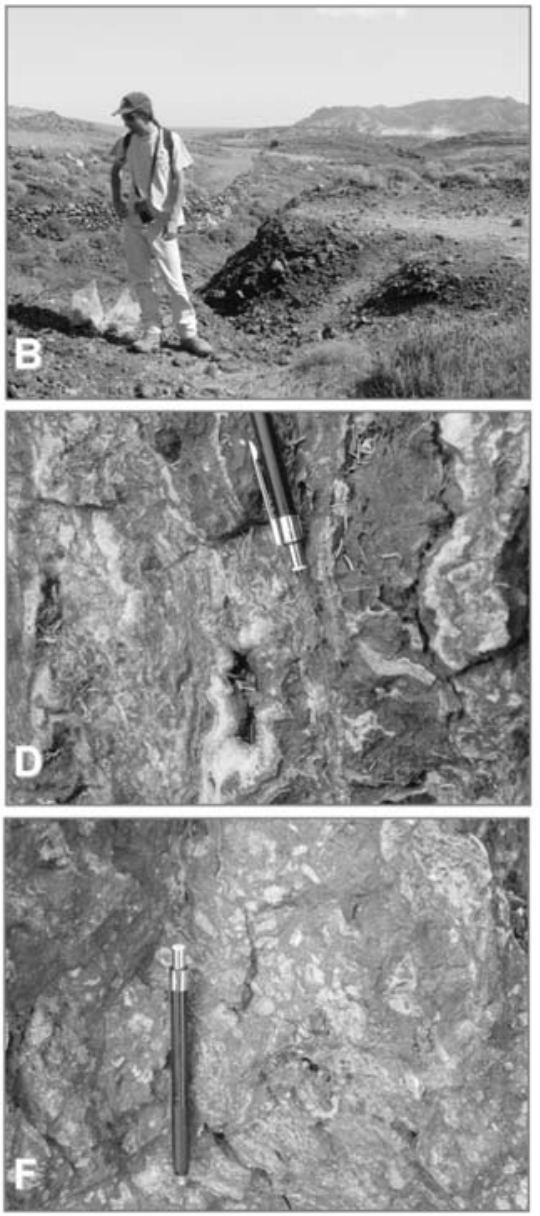

Fig. 2: A. Photo of the Korakies vein in which the banded texture, the width of the mineralized structure and an old mining gallery can be seen. B. Photo of abandoned mine workings close to the vein, where a number of samples were collected. C. Photo of the host rock of Mn mineralization which is a monomict volcaniclastic lithic breccia. Blocky hornblende - and feldspar-phyric andesite clasts (And) are separated by small amounts of millimeter to submillimeter-sized granular matrix $(\mathrm{Mx})$ of the same composition. The matrix includes splinters of andesite and scattered crystal fragments. Group of clasts in the matrix display jigsaw-fit texture. Lithic fragments are surrounded by pinkish jasper. D. Epithermal vein texture displaying: crustiform banded quartz-chalcedony-jasper intergrown with bands of manganese mineralization, and, cockade texture. E. Transitional relationship between banded quartz-Mn ore texture and hydrothermal breccia (Bx) F. Enlargement of (Bx) in previous photo. Hydrothermal fault-breccia structure consists of angular vein material and matrix with Mn-ore. (And: andesite; Mx: matrix; Bx: breccia).

to brecciation and mineralization. Primary Mn ore forms part of these textures. Banding may be related to cyclic pulses of fluid caused by a feeder mechanism in which fluid overpressure caused faulting events during low effective normal stress conditions. A supergene oxidation zone exists of Fe-Mn-oxy-hydroxides, affecting at least $5 \mathrm{~m}$ of the upper and exposed parts of the vein. 


\section{Methods}

Thirty two mineralized, host rock and vein wallrock samples where collected both in-situ and from old nearby mine rumble (Fig. 2B). The samples were examined under transmitted and reflected light microscopes, and analysed by SEM-EDS, AAS and XRD methods in the laboratories of the Dept. of Economic Geology and Geochemistry, University of Athens. We used an SEM-EDS Jeol Jsm5600 (Oxford ISIS 300 microanalysis system) with $20 \mathrm{kV}$ voltage, current of $0.5 \mathrm{nA}$, analysis time of $50 \mathrm{sec}$ and bundle diameter $<2 \mu$. For the XRD studies, a Siemens D5005 CuK $\alpha$ radiation diffractometer was used, with $1.54 \AA$ wavelength and $40 \mathrm{kV}$ voltage. The concentrations of $\mathrm{K}$ and $\mathrm{Na}$ were measured with a Jenway PFP7 flamephotometer.

\section{Mineralogy and mineral chemistry}

Hydrotermal alteration: Due to overprint of supergene oxidation, hydrothermal alteration of the host rocks is not easily discernible. It seems that it is limited to the vicinity of the main vein, to an unknown extent. The most common minerals present in altered wall rock are quartz, adularia, Baadularia, illite (sericite), chlorite, and Fe-oxides. The main alteration type is quartz-adularia+chlorite \pm illite. Quartz is mainly present as a pervasive replacement of the volcanic host rock matrix, whereas adularia, illite and chlorite grow over feldspar and hornblende clasts and crystal fragments of the groundmass (Fig. 3B). Traces of Mn-ilmenite were also found.

Manganese minerals: Primary manganese ore essentially consists of pyrolusite and intermixed hollandite-group Mn-oxide minerals (hollandite-cryptomelane-coronadite). Gangue minerals are quartz, chalcedony, jasper, barite, minor adularia and illite. Supergene minerals are iron oxides and hydroxides, and Mn-Fe wad. Formation of manganese, and iron, minerals may have been controlled by Eh changes, under either hypogene and/or supergene oxidizing conditions, or both (i.e. ascending and/or descending fluids) (see Figure 3C\&D); temperature and Eh (oxidized sulfur) changes, may have caused gangue precipitation, and barite, respectively (e.g. Leal et al., 2008). Pyrolusite appears as masses of well-formed rhombohedral to prismatic and needle-like crystals that may reach a few millimeters in size. Hollandite-group minerals occur mainly as repetitive colloform microbands with variable grain size and porosity that commonly follow the same succession of precipitation (Fig. 3C), or vug filling wad (Fig. 3D\&E). Goethite is the most common iron oxide; it is present as a botryoidal aggregate and usually occurs with hematite. Electron microprobe analyses of Mn minerals are shown in Table 1.

\section{Geochemistry}

Whole rock chemical analyses of manganese ores are shown in Table 2. The ore samples may contain up to $25.83 \% \mathrm{Mn}, 14.7 \% \mathrm{Fe}, 2860 \mathrm{ppm} \mathrm{Zn,} 1132 \mathrm{ppm} \mathrm{Pb}, 136 \mathrm{ppm} \mathrm{Cu}$ and $3780 \mathrm{ppm} \mathrm{Ba}$, while concentrations in $\mathrm{Ni}$ and $\mathrm{Co}$ are very low. In addition, concentrations of $4.3 \% \mathrm{Na}, 0.75 \% \mathrm{~K}, 0.77 \%$ $\mathrm{Ca}$, and $0.09 \% \mathrm{Mg}$ have been measured. According to the correlations between all elements, they can be subdivided into different groups; $\mathrm{Mn}$ and $\mathrm{Zn}$ show mutual positive correlation (correlation coefficient $\mathrm{r}^{2}=0.61$ ) indicating that $\mathrm{Zn}$ is associated with the manganese oxide phase; $\mathrm{Fe}-\mathrm{Pb}-\mathrm{Cu}-\mathrm{Zn}$ and $\mathrm{Cr}$ show mutual positive correlation $\left(\mathrm{r}^{2}=0.74-0.99\right)$, suggesting that some of these elements may be adsorbed onto supergene goethite and hematite, however, association with Mn minerals cannot be excluded. $\mathrm{Na}, \mathrm{K}, \mathrm{Al}$ and $\mathrm{Ca}$ show positive mutual correlations but do not have a statistically significant correlation with $\mathrm{Fe}, \mathrm{Mn}$, or $\mathrm{Si}-\mathrm{Al}$. These elements are probably partitioned among all those phases, but predominantly with an aluminosilicate phase. The high Na content may suggest involvement of seawater (Hein et al., 2008); Mg does not correlate with any other element and may also originate from seawater. The $\mathrm{Ca}$ content probably reflects a carbonate sediment source. 

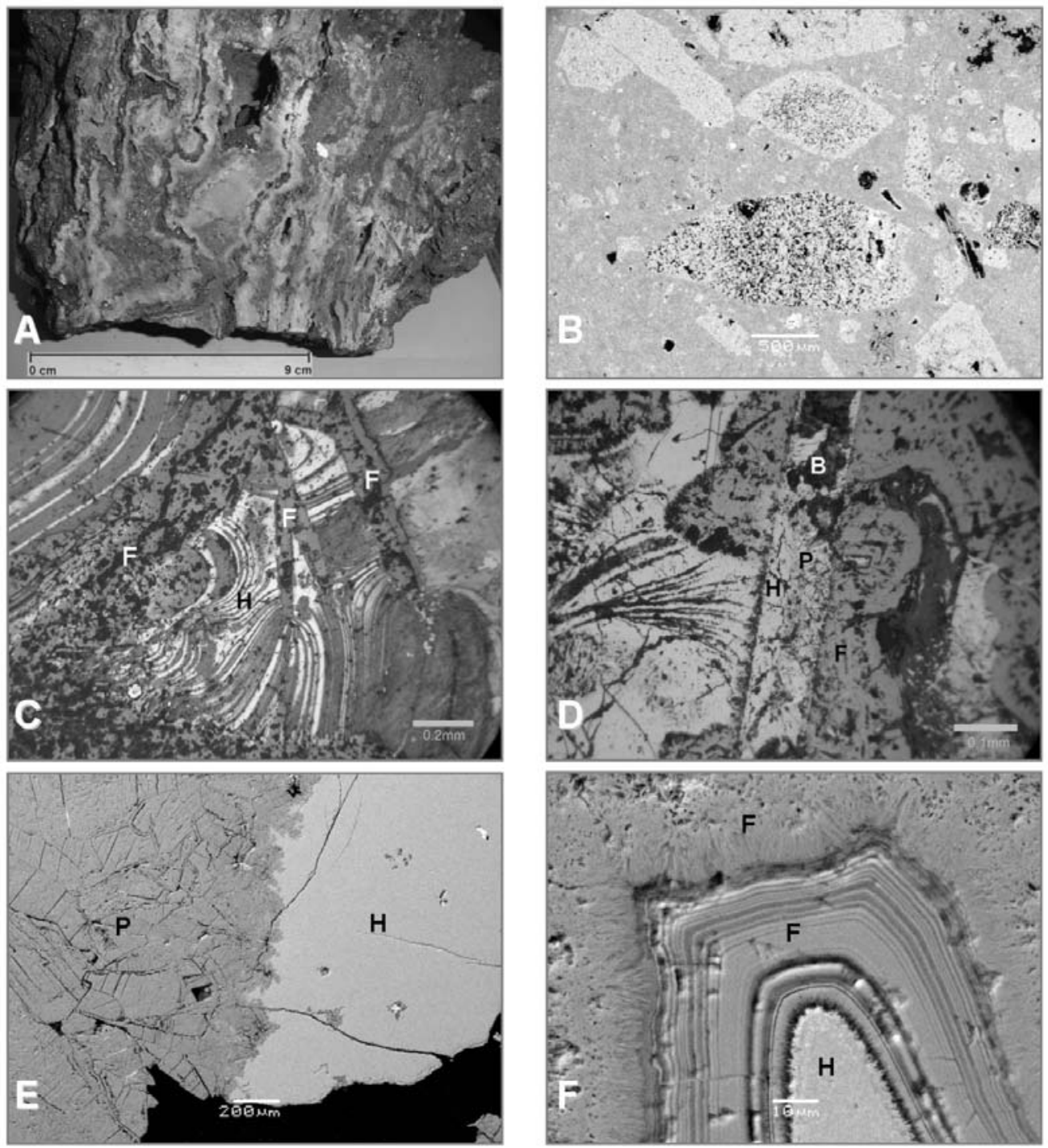

Fig. 3: A. Polished section showing Mn-ore forming part of epithermal-style crustiform banding, vugs and cockade structures. B. Back-scattered electron image of hydrothermally altered wallrock. Equant to cuneiform andesite clasts are packed in a matrix that contains scattered crystal fragments. The clasts consist of feldspar and hornblende altered to Ba-adularia, chlorite, illite, and quartz; groundmass comprises fine-grained silica and altered feldspar and hornblende. C. Microphotograph of colloform hollandite (light grey) cut by hematite and goethite. D. Microphotograph of hollandite wad and pyrolusite within an older elongate barite crystal; goethite-hematite are the supergene phase E. Back-scattered electron image illustrating primary assemblages of pyrolusite (P) and hollandite/coronadite (H). F. Back-scattered electron image of finely laminated bulbous and smooth undulating aggregates of Fe-rich (goethite-hematite) phases, of possible biogenic (microbial) origin (P:pyrolusite; H:hollandite/coronadite; B: barite; F: goethite-hematite) 
Table 1. Electron microprobe analyses (wt $\%$ ) of selected manganese oxides from Korakies. Samples 1-13: hollandite - cryptomelane, 14-17: hollandite - coronadite, 18-26: pyrolusite, 27-36: goethite - hematite (n.d= not detected).

\begin{tabular}{|c|c|c|c|c|c|c|c|c|c|c|c|c|}
\hline & $\mathrm{MgO}$ & $\mathrm{Al}_{2} \mathrm{O}_{3}$ & $\mathrm{SiO}_{2}$ & $\mathrm{~K}_{2} \mathrm{O}$ & $\mathrm{CaO}$ & $\mathrm{MnO}_{2}$ & $\mathrm{Fe}_{2} \mathrm{O}_{3}$ & $\overline{\mathrm{ZnO}}$ & $\mathrm{BaO}$ & $\overline{\mathrm{PbO}}$ & $\mathrm{As}_{2} \mathrm{O}_{3}$ & TOTAL \\
\hline 1 & 0.5 & n.d & n.d & 4.5 & n.d & 80.4 & 1.7 & n.d & 5.8 & n.d & n.d & 93.3 \\
\hline 2 & 1.0 & n.d & 0.3 & 1.5 & 0.2 & 81.1 & n.d & 0.7 & 6.2 & n.d & n.d & 91.1 \\
\hline 3 & n.d & n.d & 0.4 & 2.8 & n.d & 76.9 & 2.2 & n.d & 7.2 & 0.6 & n.d & 90.5 \\
\hline 4 & 3.2 & n.d & n.d & 2.4 & 0.3 & 81.9 & n.d & n.d & 7.2 & n.d & n.d & 95.3 \\
\hline 5 & 1.0 & n.d & n.d & 2.3 & n.d & 79.0 & n.d & n.d & 7.2 & n.d & n.d & 90.4 \\
\hline 6 & 3.3 & n.d & n.d & 2.5 & n.d & 83.1 & n.d & 0.6 & 7.3 & n.d & n.d & 97.3 \\
\hline 7 & n.d & n.d & n.d & 2.0 & 0.2 & 80.3 & n.d & n.d & 7.4 & n.d & n.d & 90.8 \\
\hline 8 & 1.1 & n.d & n.d & 1.3 & n.d & 79.7 & n.d & 0.8 & 7.5 & 0.1 & n.d & 90.5 \\
\hline 9 & 3.2 & n.d & n.d & 2.5 & 0.4 & 82.5 & n.d & n.d & 7.5 & n.d & n.d & 96.7 \\
\hline 10 & n.d & n.d & 0.8 & 0.7 & 0.6 & 65.2 & 3.6 & 0.8 & 10.8 & n.d & n.d & 82.6 \\
\hline 11 & n.d & n.d & 0.3 & 1.7 & 0.3 & 75.9 & 1.9 & n.d & 9.9 & n.d & n.d & 91.2 \\
\hline 12 & n.d & n.d & n.d & 1.0 & n.d & 77.6 & n.d & 0.8 & 12.5 & n.d & n.d & 92.8 \\
\hline 13 & n.d & n.d & n.d & 1.2 & n.d & 76.8 & 0.9 & n.d & 12.7 & n.d & n.d & 92.5 \\
\hline 14 & n.d & n.d & 0.8 & 0.3 & n.d & 68.3 & n.d & 0.8 & 1.5 & 28.0 & n.d & 99.7 \\
\hline 15 & n.d & n.d & 0.7 & 0.2 & n.d & 68.0 & n.d & 0.7 & 1.5 & 28.1 & n.d & 99.2 \\
\hline 16 & n.d & n.d & 0.8 & n.d & n.d & 66.1 & n.d & 0.9 & 1.3 & 28.5 & n.d & 97.8 \\
\hline 17 & n.d & n.d & 0.8 & n.d & n.d & 65.8 & n.d & 0.8 & 1.1 & 28.7 & n.d & 97.2 \\
\hline 18 & n.d & n.d & 0.7 & 0.2 & 0.3 & 87.0 & n.d & 0.7 & 2.2 & n.d & n.d & 91.7 \\
\hline 19 & n.d & n.d & 1.2 & 0.2 & n.d & 87.2 & 0.6 & n.d & 1.7 & n.d & n.d & 91.7 \\
\hline 20 & 0.4 & n.d & 0.6 & n.d & n.d & 89.2 & n.d & 0.6 & n.d & n.d & n.d & 91.4 \\
\hline 21 & n.d & n.d & 0.5 & n.d & n.d & 89.3 & n.d & n.d & n.d & n.d & n.d & 90.3 \\
\hline 22 & n.d & n.d & 0.7 & n.d & n.d & 89.4 & n.d & 1.1 & n.d & n.d & n.d & 91.6 \\
\hline 23 & n.d & n.d & n.d & n.d & n.d & 89.9 & n.d & n.d & n.d & n.d & n.d & 91.1 \\
\hline 24 & 1.1 & n.d & 0.8 & n.d & n.d & 90.0 & n.d & n.d & n.d & n.d & n.d & 92.7 \\
\hline 25 & n.d & n.d & 0.7 & 0.0 & n.d & 90.6 & n.d & 0.7 & n.d & n.d & n.d & 92.7 \\
\hline 26 & n.d & n.d & 1.1 & n.d & n.d & 90.7 & n.d & 0.9 & n.d & n.d & n.d & 92.3 \\
\hline 27 & n.d & n.d & 3.0 & n.d & n.d & 3.5 & 87.3 & n.d & n.d & n.d & 1.0 & 95.2 \\
\hline 28 & n.d & n.d & 5.7 & n.d & 0.2 & 21.1 & 58.2 & 3.0 & 0.5 & n.d & 1.7 & 90.8 \\
\hline 29 & n.d & 0.4 & 6.5 & n.d & 0.2 & 18.2 & 61.3 & 2.9 & 0.5 & n.d & 2.2 & 91.8 \\
\hline 30 & n.d & n.d & 2.8 & n.d & 0.8 & 4.1 & 73.7 & 1.1 & n.d & n.d & 4.8 & 87.7 \\
\hline 31 & 1.4 & n.d & 6.5 & n.d & n.d & 1.7 & 74.4 & 2.0 & n.d & 0.2 & n.d & 86.5 \\
\hline 32 & n.d & n.d & 7.5 & n.d & 0.2 & 2.5 & 74.7 & 1.2 & n.d & n.d & n.d & 85.7 \\
\hline 33 & n.d & n.d & 5.2 & n.d & n.d & n.d & 73.8 & 1.2 & n.d & n.d & n.d & 83.0 \\
\hline 34 & 1.2 & n.d & 6.5 & n.d & n.d & 1.4 & 74.7 & 1.4 & n.d & n.d & n.d & 85.6 \\
\hline 35 & n.d & n.d & 6.7 & n.d & 0.4 & 2.9 & 67.1 & 1.5 & n.d & n.d & n.d & 79.7 \\
\hline 36 & n.d & 0.5 & 4.2 & n.d & n.d & 0.7 & 79.5 & 1.3 & n.d & n.d & n.d & 86.1 \\
\hline
\end{tabular}


Table 2. Major element (wt\%) and selected trace element (ppm) content with the resulting $\mathrm{Mn} / \mathrm{Fe}$ ratios of the Mn ore samples.

\begin{tabular}{|c|c|c|c|c|c|c|c|c|c|c|c|c|}
\hline Sample & 1 & 2 & 3 & 4 & 5 & 6 & 7 & 8 & 9 & 10 & 11 & 12 \\
\hline (wt \%) & & & & & & & & & & & & \\
\hline $\mathbf{M n}$ & 4.88 & 9.57 & 4.49 & 3.76 & 17.08 & 25.75 & 18.02 & 1.18 & 17.91 & 25.83 & 10.20 & 10.97 \\
\hline $\mathbf{F e}$ & 2.68 & 3.06 & 5.33 & 1.57 & 14.70 & 4.84 & 4.79 & 1.64 & 1.93 & 3.97 & 1.82 & 7.77 \\
\hline $\mathbf{N a}$ & 4.30 & 2.07 & 1.26 & 1.78 & 2.09 & 1.25 & 3.02 & 0.87 & 1.99 & 0.35 & 0.46 & 0.33 \\
\hline $\mathbf{K}$ & 0.53 & 0.35 & 0.24 & 0.31 & 0.50 & 0.17 & 0.75 & 0.13 & 0.29 & 0.28 & 0.14 & 0.21 \\
\hline $\mathbf{A l}$ & 2.29 & 0.91 & 0.56 & 0.79 & 0.85 & 0.50 & 1.13 & 0.23 & 0.22 & 0.24 & 0.23 & 0.12 \\
\hline$(\mathrm{ppm})$ & & & & & & & & & & & & \\
\hline $\mathbf{Z n}$ & 860 & 651 & 1045 & 336 & 2860 & 2835 & 1962 & 202 & 488 & 1047 & 657 & 1796 \\
\hline $\mathbf{P b}$ & 296 & 375 & 136 & 69 & 1132 & 174 & 189 & 87 & 60 & 626 & 121 & 447 \\
\hline $\mathbf{N i}$ & 57 & 79 & 39 & 30 & 70 & 48 & 47 & 77 & 50 & 20 & 30 & 49 \\
\hline $\mathbf{C o}$ & 48 & 30 & 19 & 20 & 60 & 48 & 94 & 38 & 40 & 29 & 30 & 29 \\
\hline $\mathbf{C u}$ & 29 & 49 & 39 & 40 & 119 & 29 & 75 & 29 & 30 & 78 & 61 & 136 \\
\hline $\mathbf{C r}$ & 96 & 108 & 194 & 59 & 447 & 183 & 160 & 58 & 70 & 127 & 71 & 252 \\
\hline $\mathbf{M g}$ & 783 & 335 & 261 & 633 & 715 & 646 & 547 & 366 & 507 & 695 & 848 & 330 \\
\hline $\mathbf{C a}$ & 7727 & 740 & 823 & 742 & 1549 & 1080 & 3745 & 558 & 617 & 1321 & 646 & 553 \\
\hline $\mathbf{B a}$ & 2259 & 2395 & 1983 & 1294 & 3780 & 1995 & 1894 & 1629 & 1450 & 2458 & 1970 & 2109 \\
\hline
\end{tabular}

The relatively high amount of some elements, such as $\mathrm{Pb}, \mathrm{Zn}, \mathrm{Cu}$, and $\mathrm{Ba}$, provides evidence of the genetic role of hydrothermal solutions (Nicholson, 1992). Some of the elements permit differentiation between manganese oxides formed in fresh water, shallow-marine and marine environment, whereas others distinguish between manganese oxides formed under surface conditions and those precipitated at deeper levels (Nicholson, 1992). For the manganese deposit described in this paper, the oxides must have precipitated under hydrothermal conditions (Fig. 4B), from fluids with a marine component, possibly in a sub-seafloor environment (Fig. 4A).

Hydrothermal enrichment of $\mathrm{Zn}$ in manganese deposits has been mentioned from the Galapagos area (Moore and Vogt, 1976, Cronan, 1986, Rogers, 1996), the Mariana-Bonin arc (Hein et al., 2008) and the Tonga-Kermadec Ridge and Lau Basin (Rogers et al., 2001). According to Cronan (1986), Hein et al. (2000), and Rogers et al. (2001), Zn enrichment in manganese deposits may represent the proximity of sulfide deposits that may be located near or below the $\mathrm{Zn}$ rich zones.

In terms of the geological, geochemical and mineralogical characteristics, Kimolos shares similarities with volcanic-hosted epithermal systems (Hedenquist et al., 2000). This is a rare example of a vein-type epithermal-style hydrothermal manganese deposit formed in a submarine environment (Roy, 1968, 1997; Canet et al., 2005; Leal et al., 2008). 

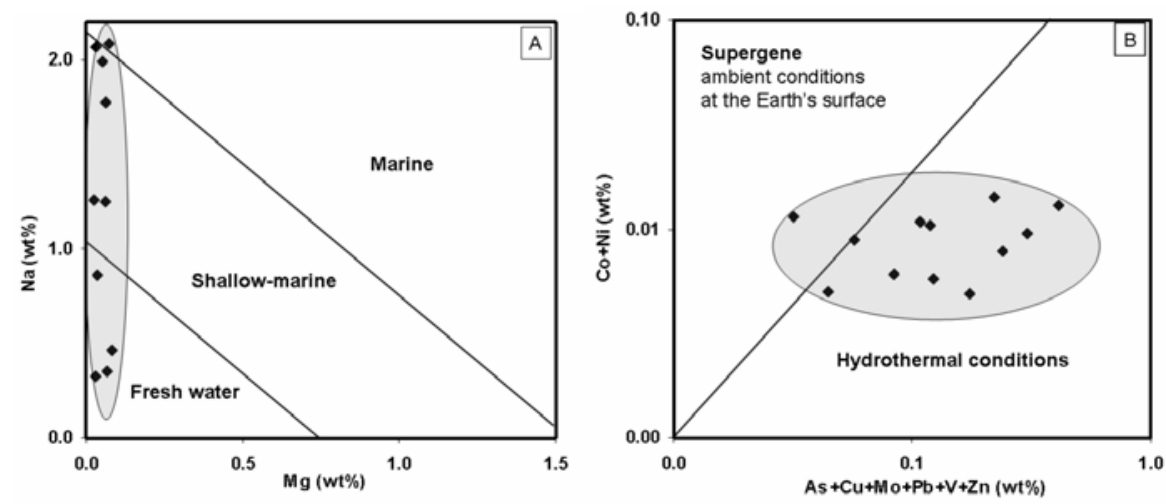

Fig. 4: A. Geochemical signature of manganese oxides from Korakies. A. Marine signature. B. Hydrothermal signature (after Nicholson, 1992).

\section{Conclusions}

As a result of the present study the following conclusions can be drawn:

1. Base metal-rich manganese oxide mineralization is hosted by a possibly subaqueous monomictic andesitic volcaniclastic lithic breccia, possibly an andesitic in situ hyaloclastite, and shallowmarine or subaerial epiclastic conglomerates, in the Korakies area in NE Kimolos. The deposit has been exploited in the past. Exploitation was centered in a main vein that fills extensional NNESSW tectonic lineaments; it has maximum width of 5-6 m, extends for $\sim 250 \mathrm{~m}$, and has unknown depth. The distribution of the mineralized structures coincides with Pliocene NE-SW regional tectonic lineaments, along which the volcanic centres of the island were developed.

2. The vein displays complex and multiepisodic filling with textures characteristic of epithermal open-space precipitation such as crustiform banding, asymmetric banding, vugs, hydrothermal breccias, and cockade and comb textures. The Mn ore forms part of these textures. Ore formation occurred by hydrothermal solutions at shallow depths and at low temperatures.

3. Hydrothermal alteration associated with the mineralization is weak and confined to less than $2 \mathrm{~m}$ around the vein, and includes silicification (quartz-adularia and quartz-illite) and propylitization (chlorite-illite). Metallic ore minerals include basically primary pyrolusite and oxides of the isostructural series hollandite-cryptomelane-coronadite, and supergene goethite and hematite. Gangue minerals include quartz, chalcedony, jasper, barite and adularia.

4. The ore contains up to $25.83 \% \mathrm{Mn}, 14.7 \% \mathrm{Fe}, 2860 \mathrm{ppm} \mathrm{Zn}, 1132 \mathrm{ppm} \mathrm{Pb}, 136 \mathrm{ppm} \mathrm{Cu}$, and $3780 \mathrm{ppm} \mathrm{Ba}$. In addition, concentration of $4.3 \% \mathrm{Na}, 0.75 \% \mathrm{~K}, 0.77 \% \mathrm{Ca}$ and $0.09 \% \mathrm{Mg}$ has been measured.

5. Seawater together with subordinate contribution of meteoric sources could have been the source(s) for the mineralizing fluids, which formed the deposit in a subseafloor environment.

6. All geological, geochemical and mineralogical evidence compiled in this paper indicate that the Mn deposit of Korakies is similar to volcanic-hosted low-sulfidation epithermal ore deposits, deposited by neutral $\mathrm{pH}$ fluids. This is a rare example of a vein-type epithermal-style hydrothermal manganese deposit formed in a marine environment (Canet et al., 2005, Leal et al., 2008). 


\section{Acknowledgements}

This work is based on the first author's B.Sc. thesis. E. Michailidis, I. Mitsis, V. Skounakis and D. Alexakis are all thanked for providing technical support. Many thanks to K. Detsi for her help in this study. Financial support from the University of Athens, Special Account for Research Grants S. P. Kilias (KA 70/4/3373, 70/4/6425) is gratefully acknowledged.

\section{References}

Alfieris, D., and Voudouris, P., 2007. High- and intermediate sulphidation Au-Ag-Te mineralization in a shallow submarine setting, Milos island, Greece: Mineralogy and geological environment of formation. In "Digging Deeper" C.J. Andrew et al (editors), v. 2, p. 893-896.

Canet, C., Prol-Ledesma, R.M., Proenza, J.A., Rubio-Ramos, M.A., Forrest, M.J., Torres-Vera, M.A., and Rodriguez-Diaz, A.A., 2005. Mn-Ba-Hg mineralization at shallow submarine hydrothermal vents in Bahia Concepcion, Baja California Sur, Mexico, Chemical Geology, v. 224, I. 1-3, p. 96-112.

Christidis, G.E, 2001. Formation and growth of smectites in bentonites, a case study from Kimolos Island, Aegean, Greece, Clays and Clay Minerals, v. 49, p. 204-215.

Cronan, D.S., 1986. Geochemical exploration for deep sea mineral deposits. In Thornton, I., Howarth, R., Graham and Trotman (eds), Applied Geochemistry in the 1980's, London, p. 241-259.

Francalanci, L., Vougioukalakis, G.E., and Fytikas, M., 2007. Petrology and volcanology of Kimolos and Polyegos volcanoes within the context of the South Aegean arc, Greece, GSA Special Papers, v. 418, p. 33-65.

Fytikas, M., Innocenti, F., Kolios, N., Manetti, P., Mazuolli, R., Poli, G., Rita, F., and Villari, L., 1986. Volcanology and petrology of volcanic products from the island of Milos and neighbouring islets, J.volcanol.geotherm, Res. 28, p. 297-317.

Fytikas, M., and Vougioukalakis, G., 1993. Volcanic structure and evolution of Kimolos and Polyegos (Milos Island Group), Bull.Geol.Soc.Greece, v. 28, p. 221-237.

Glasby, G.P., Papavassiliou, C.T., Mitsis, J., Valsami-Jones, E., Liakopoulos, A., and Renner, R.M., 2005. The Vani manganese deposit, Milos Island, Greece: A fossil stratabound Mn-Ba-Pb-Zn-As-Sb-Wrich hydrothermal deposit. In Fytikas, M. and Vougioukalakis, G.E. (eds), Developments in Volcanology, Elsevier, Amsterdam, v. 7, p. 255-288.

Hauck, M., 1984. The barite deposits of Milos Island Greece. Unpubl.PhD Thesis, Univ. Karlsruhe, 241 pp (in German).

Hedenquist, J.W., Arribas, A., and Conzalez-Urien, E., 2000. Exploration for epithermal gold deposits, Reviews in Economic Geology, v. 13, p. 245-278.

Hein, J.R., Stamatakis, M.G., and Dowling, J.S., 2000. Trace metal-rich Quaternary hydrothermal manganese oxide and barite deposit, Milos Island, Greece, Applied Earth Science, section B, v. 109, p. 6776.

Hein, J.R., Schulz, M.S., Dunham, R.E., Stern, R.J., and Bloomer, S.H., 2008. Diffuse flow hydrothermal manganese mineralization along the active Mariana and southern Izu-Bonin arc system, western Pacific, J. Geophys. Res., v. 113, B08S14.

Kilias, S.P., Naden, J., Cheliotis, I., Shepherd, T.J., Constandinidou, H., Crossing, J., and Simos, I., 2001. Epithermal gold mineralization in the active Aegean volcanic arc: The Profitis Ilias deposit, Milos Island, Greece, Mineralium Deposita, v.36, p. 32-44.

Kilias, S.P., Detsi, K., Godelitsas, A., Typas, M., Naden, J., and Marranitos, Y., 2007. Evidence of Mnoxide biomineralization, Vani Mn deposit, Milos, Greece. In "Digging Deeper" C.J. Andrew et al (editors), v. 2, p. 1069-1072. 
Leal, P.R., Correa, M.J., Ametrano, S .J., Etcheverry, R.O., Milka, K., and de Brodtkorb, 2008. The manganese deposits of the Pampean Ranges, Argentina, Canadian Mineralogist, v. 46, p. 1215-1233.

Liakopoulos, A., Glasby, G.P., Papavassiliou, C.T., and Boulegue, J., 2001. Nature and origin of the Vani manganese deposit, Milos, Greece: an overview, Ore Geology Reviews, v. 18, p. 181-209.

Moore, W.S., and Vogt, P.R., 1976. Hydrothermal manganese crusts from two sites near the Galapagos spreading axis: Earth Planet, Sci. Lett. v. 29, p. 349-356.

Naden, J., Kilias, S.P., Leng, M.J, and Cheliotis, I., 2003. Do fluid inclusions preserve $\delta 18 \mathrm{O}$ values of hydrothermal fluids in epithermal systems over geological time? Evidence from paleo- and modern geothermal systems, Milos Island, Aegean Sea, Chemical geology, v. 197, p. 143-159.

Naden, J., Kilias, S.P., and Darbyshire, D.P.F., 2005. Active geothermal systems with entrained seawater as analogues for transitional continental magmato-hydrothermal and volcanic-hosted massive sulfide mineralization-the example of Milos Island, Greece, Geology, v. 33, p. 541-544.

Nicholson, K., 1992. Contrasting Mineralogical-Geochemical Signatures of Manganese Oxides: Guides to Metallogenesis, Economic Geology, v. 87, p. 1253-1264.

Pe, G.G., and Piper, D.J.W., 1972. Volcanism at subduction zones; The Aegean area, Bull. Geol. Soc. Greece, v. 9, p. 113-144.

Pe-Piper, G., and Piper, D.J.W., 2002. The Igneous rocks of Greece, Berlin, Gebruder Borntraeger, 573 pp.

Plimer, I., 2000. Milos Geologic history, KOAN Publishing House, Athens, 262 pp.

Post, J.E., 1999. Manganese oxide minerals: Crystal structures and economic and environmental significance, Proc. Natl. Acad. Sci. USA, v. 96, p. 3447-3454.

Rogers, T.D.S., 1996. The geochemistry of ferromanganese crusts and sediments from the southern Pacific, Ph.D. Thesis, University of London.

Rogers, T.D.S., Hodkinson, R.A., and Cronan D.S., 2001. Hydrothermal Manganese Deposits from the Tonga-Kermadec Ridge and Lau Basin Region, Southwest Pacific, Marine Georesources and Geotechnology, v. 19, p. 245-268.

Roy, S., 1968. Mineralogy of the different genetic types of manganese deposits, Econ. Geol., v. 63, p. 760786.

Roy, S., 1997. Genetic Diversity of Manganese Deposition in the Terrestrial Geological Record. In Nicholson, K., Hein, J.R., Biihn, B. and Dasgupta, S. (eds), Manganese Mineralization: Geochemistry and Mineralogy of Terrestrial and Marine Deposits, Geological Society Special Publication, No. 119, p. 5-27.

Skarpelis, N., and Koutles, T., 2004. Geology of epithermal mineralization of the NW part of Milos Island: Greece, 5th International Symposium on Eastern Mediterranean Geology, Thessaloniki, Greece.

Stewart, A.L., and Mcphie, J., 2006. Facies architecture and Late Pliocene - Pleistocene evolution of a felsic volcanic island, Milos, Greece, Bulletin Volcanology, v. 68, p.703-726. 